
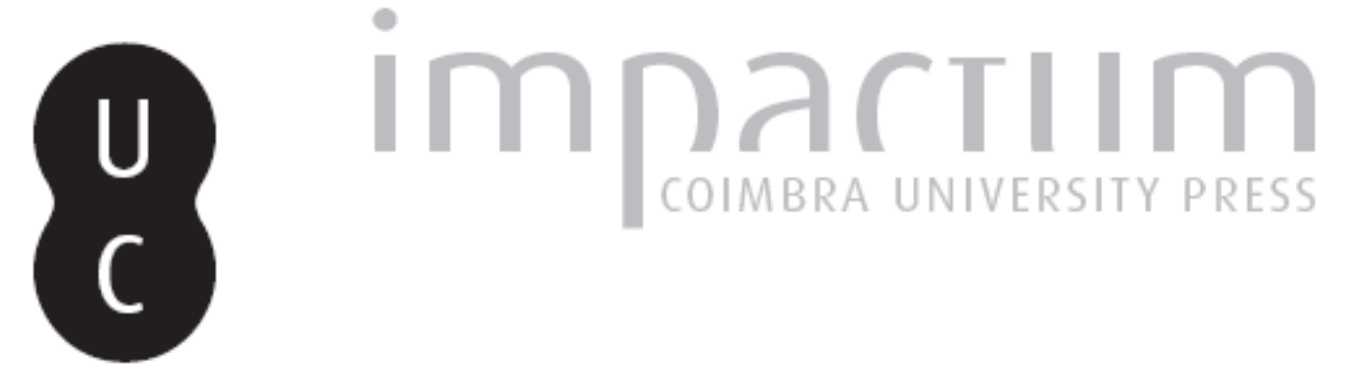

\title{
[Recensão a] Salvador Bravo Jiménez, Control ideológico y territorial en el Estrecho de Gibraltar en la Antigüedad (Siglos X-I a.C.)
}

Autor(es): Bailón García, Marta

Publicado por: Faculdade de Letras da Universidade de Coimbra

URL persistente:

URI:http://hdl.handle.net/10316.2/37124

DOI:

DOI:http://dx.doi.org/10.14195/1647-8657_52_7

Accessed : $\quad$ 26-Apr-2023 10:55:56

A navegação consulta e descarregamento dos títulos inseridos nas Bibliotecas Digitais UC Digitalis, UC Pombalina e UC Impactum, pressupõem a aceitação plena e sem reservas dos Termos e Condições de Uso destas Bibliotecas Digitais, disponíveis em https://digitalis.uc.pt/pt-pt/termos.

Conforme exposto nos referidos Termos e Condições de Uso, o descarregamento de títulos de acesso restrito requer uma licença válida de autorização devendo o utilizador aceder ao(s) documento(s) a partir de um endereço de IP da instituição detentora da supramencionada licença.

Ao utilizador é apenas permitido o descarregamento para uso pessoal, pelo que o emprego do(s) título(s) descarregado(s) para outro fim, designadamente comercial, carece de autorização do respetivo autor ou editor da obra.

Na medida em que todas as obras da UC Digitalis se encontram protegidas pelo Código do Direito de Autor e Direitos Conexos e demais legislação aplicável, toda a cópia, parcial ou total, deste documento, nos casos em que é legalmente admitida, deverá conter ou fazer-se acompanhar por este aviso.

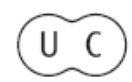


CONIMBRIGA

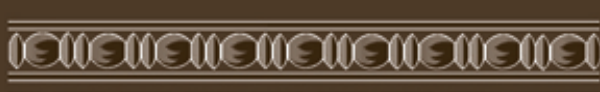

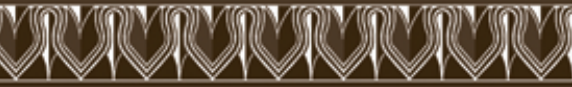

INSTITUTO DE ARQUEOLOGIA

VOLUME LII • 2013

FACULDADE DE LETRAS

UNIVERSIDADE DE COIMBRA 


\section{RECENSÕES BIBLIOGRÁFICAS}

Salvador Bravo JimÉnEz, Control ideológico y territorial en el Estrecho de Gibraltar en la Antigüedad (Siglos X-I a.C.). Ceuta, Instituto de Estudios Ceutíes, 2014, 441 pp. [ISBN: 978-84-92627-76-9]

El presente trabajo es el resultado de un análisis exhaustivo y riguroso sobre el marco geográfico del Estrecho de Gibraltar dentro de la Antigüedad, abarcando los períodos históricos desde la colonización fenicia hasta la Roma Republicana. El estudio queda dividido en seis capítulos, entre los que se realiza el examen del medio físico, del origen mítico de este espacio geográfico relacionado con el Extremo Occidente y con los límites de lo conocido, de los períodos de ocupación fenicio, cartaginés y romano, para concluir con un amplia exposición sobre la historia de los enclaves urbanos de la zona, desde su fundación hasta época republicana.

El autor efectúa un estudio geográfico profundo de la zona a estudiar: el Estrecho de Gibraltar. La investigación incluye la localización geoespacial del territorio y los aspectos más destacados de su geomorfología, factores climáticos importantes como la acción del viento en la zona, la climatología y agentes que influyen en su constitución. La observación preliminar de todos estos elementos resulta imprescindible para comprender el medio en el cual las civilizaciones antiguas ocuparon el territorio.

El marco físico del Estrecho de Gibraltar queda contemplado desde la perspectiva recogida por autores clásicos como Diodoro Sículo o Estrabón, relacionando el territorio con la mitología, con las vías de comunicación y con el comercio existente en la zona.

Los autores antiguos contemplaban el mundo como un territorio finito, estableciendo el límite físico occidental en torno al Estrecho de Gibraltar. Entre Gadir y Lixus quedó fijada la puerta o acceso que conectaba el mundo de los vivos con el Más Allá, tradición asentada desde época fenicia. Posteriormente este lugar recibió el nombre de Columnas de Melkart (posteriormente Heracles) y constituyó el final del mundo conocido.

El examen de la presencia fenicia en el territorio data del siglo VIII a.C., teniendo un período de adaptación y ocupación posterior hasta el siglo VI a.C. A partir de ese momento las regiones de los Elbestios y Mastianos aparecieron vinculadas al dominio cartaginés, aunque según se recoge, parece que varios autores no vieron presencia púnica en la zona hasta la dinastía bárquida. El au- 
tor nos menciona la presencia de una confederación comercial púnica en torno a varios emplazamientos y comunidades del Estrecho de Gibraltar.

La presencia romana en el territorio del Estrecho de Gibraltar se muestra como continuidad de algunos asentamientos de tradición fenicia y púnica. Poblaciones como Gadir, Carteia o Malaka continuaron sus transacciones comerciales tradicionales relacionadas con los salazones. Al mismo tiempo se crearán asentamientos nuevos.

Roma empleó la guerra para obtener pingües beneficios en la zona, cuya finalidad última fue la expansión y anexión de la Península Ibérica. Esta política fue empleada hasta la nueva reorganización del territorio, en época de Augusto, con la creación de nuevas ciudades con rango de colonia, en las cuales se van a asentar veteranos de las legiones y nuevos ciudadanos. Las ciudades del Estrecho seguirán teniendo la misma consideración de civitatesstipendiariae, exceptuando las colonias de Carteia, Iulia Traducta, Iulia Constantia Zilil yTingi. La presencia de Roma supuso el mantenimiento de las estructuras políticas y culturales locales, y la potenciación de las oligarquías locales, expuestas al pago de tributos y a la imposición del control ideológico.

Se puede rastrear en la zona una serie de núcleos poblacionales estables en el Estrecho de Gibraltar que daban cohesión al territorio, destacándose diferencias notables entre ambas orillas. El modelo más utilizado en el norte fue el de civitas stipendiaria y en el Sur predominaron las colonias y los municipios. Por último, el autor analiza con sumo detalle las grandes unidades territoriales en torno al Estrecho de Gibraltar durante la República. Estas son: Mellaria, Baelo, Iulia Traducta, Carteia, Oba, Barbesula, Lacipo, SeptemFratres, Tamuda, Tingi yIulia Constantia Zilil.

Marta Bailón García

C. A. Madrid Sur (UNED)

Conimbriga, 52 (2013) 195-199 
